\title{
An Evaluation of Recognition on Performance as a Motivator: A Case of Eastern Cape Higher Education Institution
}

\author{
Tarisai Chikungwa \\ University of Fort Hare, Department of Industrial Psychology \\ Private Bag, X1314, Alice, 5700, Republic of South Africa \\ Email: tariechik@gmail.com; tchikungwa@ufh.ac.za
}

Shingirayi Florence Chamisa

University of Fort Hare, Department of Industrial Psychology

Private Bag, X1314, Alice, 5700, Republic of South Africa

Email:Shingirayi_chamisa@hotmail.com; rchamisa@gmail.com

Doi:10.5901/mjss.2013.v4n14p219

\begin{abstract}
Most African Universities are faced with the challenge of motivating and retaining highly qualified staff, particularly lecturers and researchers. These challenges have triggered a more calculated approach to human resources management across the higher education sector in South Africa (Kubler and DeLuca 2006). The present study investigates the impact of recognition on performance as a motivation strategy at an institution of higher learning in the Eastern Cape region of South Africa. Descriptive statistical tools where used to measure research variables. A total of 63 employees or $30 \%$ of the academic staff at of the University were sampled out of a population of 209 academic staff. The results indicated that academic employees are most satisfied and motivated through recognition of performance and achievement. This is also in support of the Herzberg theory of motivation in studies by Backer (1982). Higher education institutions must therefore take the issue of recognition of performance seriously starting from the simple techniques such as "splendid work" and "thank you" to more complex ones like the use of research incentives and awarding best staff annually or quarterly to stimulate performance.
\end{abstract}

Keywords: Recognition, performance, motivation, rewards

\section{Introduction}

Human resources are the most vital asserts of the organisation. Retaining efficient and experienced workers in the organisation is very essential in the overall performance of any organisation. Equally the maintenance, administration and development of human resources cannot be undervalued. Motivated employees make an organization to be more competitive and consequently marketable (Danisha and Usman, 2010). Additionally most organisations have realised the importance of establishing a fair balance between employees' contribution to the organisation and vice versa (Md et al., 2013). Through establishing this balance employees are rewarded through recognition of their performance. Previous research on the topic (Md et al., 2013; Danisha and Usman, 2010; Manjunath and Rajesh, 2012; Harrison, 2005) concluded that the most shared problem in organisations today is that they miss the important component of recognition of employee performance, which is the low-cost, high-return ingredient to a well-balanced reward system. The central principle of recognition of employee performance is to make employees feel appreciated and valued (Sarvadi, 2005). Research has proven that employees whose performance get recognised tend to have higher self-esteem, more confidence, more willingness to take on new challenges and more eagerness to be innovative (Mason, 2001).

\section{Background}

Most research has reported that the quality of staff in an organization influences directly organisational effectiveness (Du Toit, Erasmus and Strydom, 2008). Globalisation has led to the increased demand and intensified competition for highly qualified academics. The continuous shifting demographic profiles through global mobility make it almost impossible for many higher learning institutions to retain knowledgeable lectures and researchers (Bushe, 2012). The identified developments have inspired a more strategic approach to human resource management across the higher education 
sector though motivation (Kubler and DeLuca 2006).

Motivation is defined by Baron (1983) as an accrual of diverse practices which impact and direct behavior to achieve a specific goal. Also Kreitner and Kinici (2004) accept that motivation encompasses psychological practices that effect the arousal, course and persistence of voluntary activities that are goal focused. Motivation however depends on positive intrinsic, as well as, extrinsic factors which in association results in fully committed employees. According to Boad (2007), physical incentives are effective in increasing performance for future tasks to encourage "thinking smarter" and to support both quality and quantity to achieve goals. Incentives, rewards and recognition of performance are the principal factors that influence employee motivation. In Herzberg's Two-Factor Theory of Motivation, recognition of performance together with sense of achievement, increased responsibility and personal growth and development among others were classified under intrinsic factors of motivation (Danisha and Usman, 2010).

Job performance is the job performance is the conduct that can be assessed in terms of the extent to which it adds to organisational effectiveness (Motowidlo, Borman and Schmidt 1997; Onukwube, lyabga and Fajana, 2010). Hillriegel, Jackson and Slocum (1999) view job performance as individual's work attainment after having utilised effort. Viswesveran and Ones (2000) repute it as the behavior and outcomes that employees engage in or bring about that are linked with and contribute to the achievement of organisational goals. Job performance is therefore related to the degree to which employees are able to undertake the tasks assigned to them and how the accomplished task adds to the fulfilment of the organisational goals.

Harrison (2005) defined recognition of employee performance as appropriate acknowledgement of a resulting individual's effort and output in fulfilling the organisation's goals and values beyond normal expectations. Petrescu and Simon, (2008) also defined the same term as confirmation of a given occurrence or performance. Certainly recognition of employee performance have been identified as one main factor that contributes to the motivation and retention of employees in the organisation and in turn must be embraced in any organisation that is determined to succeed in the prevailing global environment.

Recognition of performance systems are powerful means of directing attention within and organisation hence management must understand the psychology of praising employees for good work, to apply the principles of employee recognition and to encourage others to initiate it in their working relationships (Md et al., 2013). The authors went on to state that appreciation is a vital human need and that employees retort to gratitude expressed through recognition of their good work because it confirms their work is valued. Grote (2006) states that Recognition of employee performance can come is such simple forms as "Good work, Thank you, Well done, or I really appreciate it." Roshan, (2005) supports this notion by adding that employee performance and job satisfaction increases when they feel that their work is being valued, thus they are motivated to perform to their best. Stringer, Didham, \& Theivananthampillai, (2011) also adds that recognition of employee performance creates an emotional bond between staff and the institution.

Results from recent studies (Ferguson and Reio, 2010 and Bothshabelo, 2009) revealed that intrinsic motivators are good predictors of performance. Recognition of employee performance is essential in forming performance improvement relationships in organisations. It contributes to the enhancement of self-esteem among staff. According to Manjunath and Rajesh (2012), individuals already have the potential the required expertise to initiate higher performance levels, but needs to be motivated or driven through recognition of employee performance. Additionally, recognition of employee performance can also pose as a platform to address the feelings and emotions of the employees because some employees prefer only high salaries and allowances (Nolan, 2012).

The University of Fort Hare's main objectives includes conveying knowledge through instruction, research and community services. Abdulkareem and Oyeniran (2011) confirm that universities are reputable to serving as centers of technological and scientific advancement, skills development, production of quality entrepreneurial graduates, and strategic researches and development strategies. This can only be achieved through qualified and competent staff. The performance of academic staff is however a combined function of qualification and competence and motivation (Ngu, 1998; Abdulsalam and Mawoli, 2012) Ngu (1998) went on to define motivation as the passion and tenacity with which a person accomplishes tasks. This therefore means academic staff can only realise their highest performance when satisfactorily motivated.

Effective job performance by the academic staff leads to the recognition of the broad objectives for which universities are established, namely knowledge delivery, research and community services. Blanchard (2004) supports that positive performance in higher education consequently lead to positive progression. For example, effective knowledge delivery will enable skill acquisition and entrepreneurship development which will bring about poverty reduction in South Africa. Research output from the University expands the frontiers of knowledge and hasten social, economic, artistic, scientific and technological development in the society (Abdulsalam and Mawoli, 2012). 


\subsection{The relationship between Recognition of performance and performance}

Employee performance is the main element in realising the organisational goals and objectives. Employee performance is influenced with compensation. Employees need recognition of performance and appreciation in relation to achievement and accomplishments by employers and workmates. According to Shaun and York (2002), motivation is perceived as a result of the worth held by an individual on the potential results of their activities and the expectations that their targets will be realised in due course. Effective recognition of performance results to increased employee performance as a resultant of enhanced satisfaction as seen in their commitment and perseverance (Lawler, 1981).

On the other hand, recognition of performance is the acknowledgement of an employee's achievement and effort towards organizational goals (Petrescu and Simon, 2008). It includes attention to employee actions, efforts, behaviour or performance, which can be either physical or psychological or both. Recognition of performance is one way of motivating staff in an institution of higher learning thus, making them feel more valued and improving the overall attraction and employee retention (Nyakundi et al 2012).

The attraction and retention of talented and committed employees yields to better performance. This is because some employees are motivated to work an extra mile with more than basic salaries and allowances (Nolan, 2012). As such there is need for an organization to consider the provision of some relevant awards on merit as a form of recognition of employee performance. Lee and Chen (2011) further found out that one of the major reasons for lack of desired performance commitment among teaching staff could be linked to the nature and quality of compensation offered to them. Tertiary institutions can offer recognition of performance in various ways ranging from the provision of certificates, shopping vouchers, praise, trophies, and opportunity, appreciating their ideas and respect where it deserves (Nolan, 2012).

This paper aims to establish an understanding on the role of recognition of performance towards employee performance. The independent variable was recognition of performance and the dependent variable was employee actual performance.

\section{Methodology}

\subsection{Research design}

\subsubsection{Research Population, Sample size and Sampling Procedure}

At the time of the study, the University had 15 departments and 209 numbers of academic staff and research. A cross sectional survey design was used to obtain data from target population of 209 staff at the University of Fort Hare academic staff giving a sampling frame of 63 teaching and research staff combined. Stratified sampling method was used. At least 10\% of total population is appropriate (Sekaran, 2009; Saunders, et al. 2008).

\subsection{Research data and instrument for data collection}

A self-designed questionnaire was used for data collection. The questionnaire included bot closed and open ended questions. A total of 100 questionnaires where electronically administered with over sixty percent response rate. This was possible because the questionnaire was clear and strait to the point and respondents where highly literate.

The reliability of the scales were determined using Cronbach's alpha method. Analysis revealed that motivation scale is reliable by $64 \%$, and performance by $76 \%$. Cronbach's alpha measures the average of measurable items and its correlation, and if the result is generally above 0.5 (or 50\%), it is considered to be reliable (Peighambari, 2007). In this case the questionnaire presented an average of 0,7 therefore significant.

\subsection{Data Analysis and Presentation}

Data analysis was done using SPSS. All variables in the study where were measured using nominal scale - the 5 point Likert type rating scale ranging from 1 representing very unlikely to 5 equivalent to very likely. Data collected from the field were analyzed using quantitative techniques, so as to determine the relationship between the study variables; employee recognition and performance. Descriptive statistics were used to highlight the existing relationships. 


\subsection{Contribution of the study}

The results of this investigation are quite beneficial for managers and policy makers. The managers can provide recognition of performance through informal discussions with employees including informal dinner or general interest on their welfare. The study also contributes to the establishment of a formal recognition of performance or motivation strategy in tertiary institutions and other organisations. This will also serve as a channel of employees' involvement to decision making.

\section{Results}

\subsection{Demographic characteristics}

A total of 63 questionnaires were analysed in this study. Age of respondents ranged from 32- 63. All respondents had finished their Masters degrees with at least two years working at the same position. Average income of respondents was R 25000.

\subsection{Opinion details}

A further analysis on the opinion details revealed that $70 \%(46 \%+26 \%)$ of academics showed that they are likely to be satisfied and motivated around their job if they receive recognition on performance which affirms the hypotheses as postulated by Herzberg's theory. Recognition of performance leaves a long term impact on employees. Employees offerd recognition of performance perform beyond organizational expectations (Welsh, et al. 2012) and are very productive. $22 \%$ of respondents indicated that they are neutral. Very unlikely and quite unlikely had both $4 \%$ each. Herzberg found that achievement, recognition of performance and work itself were the strongest contributors to the motivation of people (Adair, 1996). Achievement and recognition for achievement have also been found to be the two strongest satisfiers in Herzberg motivation studies by Backer (1982), Senekal (1998) and Botha (2003). This is supported by the findings of this research where most of the academics (76\%) showed that they were likely to be motivated and be satisfied if they get recognition on their performance.

\subsection{Recognition on performance}

Figure 1. Recognition on performance

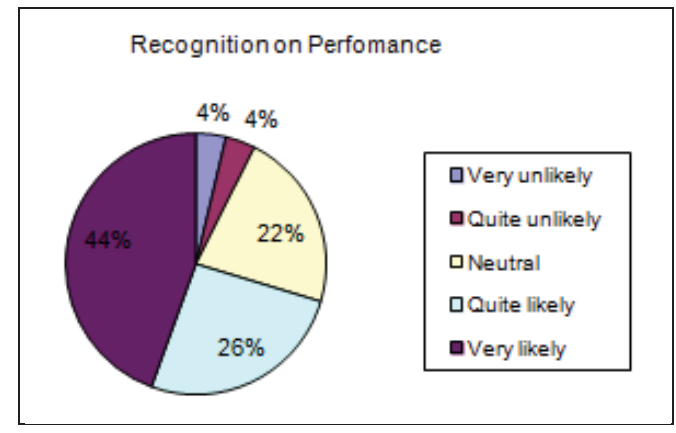

Employee retention was also discussed with respect to recognition of performance. The resultant $60 \%$ of staff were of the opinion that appreciated and praised employees are likely to stay in the institution longer due to increased job satisfaction, (Danisha and Usman, 2010; Md et al., 2013). Most instutions are heavily guarding their most equipped and committed staff from competitors.

At least $58 \%$ of respondents said that they would prefer a system of recognition of performance where various awards are established and maintained at departmental levels in the institution. These differences come with additional challenges into the institution that should be addressed through an appropriate recognition of performance policy (Nolan, 2012). 


\section{Discussion of Results}

The above findings confirm that recognition of performance recognition influences performance. Thus recognition of performance must be promoted to increase performance in tertiary institutions. People are however unique thus their performance is provoked through different things. Overally every employee has potential to perform provided they are triggered to do so (Nyakundi et al., 2012).

The results confirms the findings by Emmanuel, Kominis and Slapnicar (2008) in an investigation on the relationship between managerial motivation and performance. Managers who experience high levels of recognition of performance increased their job performance. Additionally Abejirinde (2009) investigated the relationship between motivation and work performance within private and public enterprises in Nigeria and found that promotion (as recognition of performance) and employees' performance are positively correlated.

The findings also correspond with the results of Geofrey (2010) in a study on public universities' academic staff performance and motivation using Makerere University in Uganda as a case study. Recognition of performance was found to have a significant effect on lecturers' teaching and research activities. The more staff are appreciated and praised, the more they are likely to attend to their classes, exhaust the lesson periods, read and correct students' assignments and projects among others thereby ensuring the attainment of the University objectives (Geofrey, 2010). Also Babaita (2010) revealed that recognition of performance exerts positive impact on the employees' performance in the Nigerian banking industry.

A study by (Md, et al., 2013), showed the independent variables (recognition of performance factors) explain $73.7 \%$ of the variance in employee contribution. Beta value indicates that appreciation and performance appraisal contributes major portion of the of total employee contribution.

This also concurs with the results of Nyakundi et al., (2012) on their study on recognition of performance in a Kenyan hospital. This further agrees with a study by Mitchell (2012), whose results showed that at least 17 percent of employees leave an organization due to lack of recognition of performance.

The individual differences and challenges as highlighted by the results should form a base for a recognition strategy so as to promote all employees to work to their full potential with the goals of enhancing the learning institution (Nolan, 2012).

\section{Limitations of the Study}

The data has been collected on cross-sectional basis, longitudinal data may have produced different results as the level of motivation of employees may vary at certain period of time and with growing experience. The technique of research used is survey design if mix method could have been used with interviews and qualitative data gathering techniques the result could be more generalizable. Lastly, the study setting comprised of only one institution, future research must focus on more than one institution so that results cannot be generalised.

\section{Conclusion and Recommendations}

The objective of the study was to establish an understanding on the role of recognition of performance as a motivator. The independent variable was recognition of performance and the dependent variable was performance. The results of the study confirm that recognition of employee performance influences the way in which the employee perform at work. Thus recognition of performance on employees must be promoted to increase their performance in tertiary institutions.

To overcome the challenges resulting from globalisation, it is important to focus on motivation, most importantly the recognition of employee performance that will then impact on employee contribution to the Institution as a whole. In higher education institutions each employee's contribution is of paramount importance because students need to be guided, managed and also be motivated to perform in their studies giving birth to marketable and conversant graduates. University lecturers and researchers must be sufficiently be motivated to enable effective knowledge delivery to students and uplift the standard of education.

Universities must therefore take the issue of recognition on performance seriously for example through the use of research incentives and awarding best staff annually or quarterly to stimulate performance.

Higher educational institutions must also embrace recognition of performance as a way of improving performance starting from the simple techniques such as "splendid work" to more complex ones like "recognition of the year awards". Additionally recognition of performance programmes should be designed to run throughout the year rather than waiting 
for task completion.

\section{References}

Abdulkareem, A. Y., \& Oyeniran, S. (2011). Managing the Performance of Nigerian Universities for Sustainable Development Using Data Environment Analysis. Ilorin Journal of Sociology, 3(1), 37-50.

Abdulsalam, D. and Mawoli, M.A. (2012), Motivation and job performance of academic staff of state universities in Nigeria: the case of Ibrahim Badamasi Babangida University, Lapai, Niger State. International Journal of Business \& Management, 7, (14) 142-148.

Abdulsalam, D., \& Mawoli, M. A. (2012). Motivation and Job Performance of Academic Staff of State Universities in Nigeria: The Case of Ibrahim Badamasi Babangida University, Lapai, Niger State. International Journal of Business and Manegement , 7, (14).

Abejirinde, A.A. (2009), Motivation and Workers Performance within Public and Private Enterprises in Nigeria, Lapai International Journal of Management and Social Sciences, 2. (2), 101-112.

Adair, J. (1996). Effective Motivation. How to get extraordinary results from everyone. Pan Books.UK.

assessment: Reliability generalization across studies and measures. Educational and

Babaita, I. S. (2010). An Appraisal of Employee Motivation in the Nigerian Banking Industry. Lapai Journal of Management Sciences, $1(1), 25-39$.

Backer, W. M., (1982). An Intercultural Study of Work Motivation - a useful instrument in industrial relations: South African Journal of Labour Relations, vol. 6(1).

Baron, R. A. (1983). Behaviour in organisations. New York: Allyn \& Bacon, Inc.

Blanchard, O. (2004). Economic Future of Europe. NBER Working Paper, 103(10).

Board, L. M. (2007). Coaching a stockholder on performance improvement option. ASTD International conference. Atlanta GA, USA.

Botha, J.H. (2003). The Relationship between performance evaluation and motivational patterns amongst production workers within a petro-chemical company. Unpublished M. Phil. Dissertation at the RAU, Johannesburg.

Bothshabelo, K. (2009). The Impact of Performance -Based Reward System (PBRS) on Customer's Perceived Service Outcomes. Victoria University, Unpusblished PhD Thesis.

Bushe, B. (2012). Factors that Determine Academic Staff Retention and Commitment in Private Tertiary Institutions in Botswana: Empirical Review. Global Advanced Research Journal of Management and Business Studies, 1(9),278-299.

Chenevert, D. \& Tremblay, M. (2011), Between Universality and Contingency: An International Study of Compensation Performance. International Journal of Manpower,. 32 (8), 856-878.

Danish, R. Q., \& Usman A. (2010). Impact of Reward and Recognition on Job Satisfaction and Motivation: An Empirical Study from Pakistan. International Journal of Business Management, 5(2)

Du Toit, Erasmus \& Strydom. (2008). Introduction to Business Management. (7th Ed). Cape Town: Oxford University Press Southern Africa.

Emmanuel, C.R., Kominis, G., \& Slapincar, S. (2008), The impact of target setting on managerial motivation and performance. American Accounting Association.

Ferguson, K. L \& Reio, T. (2010), Human Resource Managerial System and Firm Performance, Journal of Management Development, 29 (15), 471-494.

Geofrey, Y. (2010). Motivation and Academic Staff Performance in Public Universities in Uganda: The Case of Makerere University. Retrieved from http://dspace.mak.ac.ug/handle/123456789/1339 Accessed 20 September 2013

Grote, D. (2006). Discipline Without Punishment: The Proven Strategy That Turns Problem Employees into Superior. USA; AMACOM.

Harrison, K. (2005). Why Employee Recognition is so Important. www.cuttingedgepr.com Accessed 20 September 2013.

Hellriegel, D., Jackson, S.E. \& Slocum, J.W. (1999), Management. Cincinnati: South-Western College Publishing.

Kotler, P. \& Keller, K.I. (2010). Marketing Management. (12th ed.), New Delhi: Dorling Kindersley Pvt. Ltd.

Kreitner, R., \& A. Kinici. (2004). Organizational Behavior, 6th Edition. Boston, MA: McGraw-Hill, Irwin.

Kubler, J, DeLuca, C. (2006). Trends in academic recruitment and retention: A Commonwealth perspective. London: Association of Commonwealth Universities.

Lawler, E. (1981). Pay and Organization Development. Massachusetts: Addison-Wesley.

Lee, S \& Chen, H. (2011). Corporate Governance and Firm Value as Determinants of CEO Compensation in Taiwan: 2SLS for Panel Data Model, Management Research Review, 34 (3), 252-265.

Manjunath, V.S. \& Rajesh, C.N. (2012), Competency Based Compensation System- As a Strategic Human Resource Technique, International Journal of Manpower, 38 (7), 780-810.

Manson, S. M. (2001), 'Simplifying complexity: A review of complexity theory', Geoforum, 32 (3), 405-414.

Md, S. A., Al, S. A. S., Md. S. \& Akter. S. (2013). Relationship between Employee Recognition and Employee Contribution in Service Industry. International Journal of Business and Marketing Management, Vol. 1(1), 1-8

Mitchell, B. (2012). Recognition of Employees: Why it Matters. http://hr.blr.com/HR-news/Staffing-Training/Employee-Turnover/znRecognition-of-employees-Why-it-matters Retrieved 19 September 2013.

Motowidlo, S.J., Borman, W.C \& dan Schmit, M.J. (1997). A Theory of Individual Differences in Task and Contextual Performance. Human Performance, 10 (2): 71-83.

Ngu, S. M. (1998). Motivation Theory and Workers Compensation in Nigeria. Zaria: ABU Press. 
Nolan, S. (2012), A Look of Current Trends Data, Strategic HR Review, 11 (3) 32-54.

Nyakundi, W. K., Karanja, K., Charles, M., \& Bisobori, W.N. (2012). Enhancing the role of employee recognition towards improving performance: A survey of Keyatta National hospital Kenya. International Journal of Arts and Commerce, 1 (7).

Onukwube, H.N., lyabga, R. \& Fajana, S. (2010). The Influence of Motivation on Job Perfromance of Construction Professionals in Construction Companies in Nigeria. Royal Institution of Chartered Surveyors.

Peighambari, K. (2007). Developing and Testing a Model for Explaining Customer Retention Formation. Unpublished Master Thesis, Tarbiat Modares University.

Petrescu, A. \& Simon, R. (2008). Human Resources Management Practices and Worker's Job Satisfaction. International Journal of Manpower, 29, (7), 651-667.

Psychological Measurement, 60, 224-235.

Roshan, L.R. (2005). The relationship between rewards, recognition and motivation at an Insurance Company in the Western Cape. Unpublished Masters Thesis. University of Western Cape.

Sarvadi, P. (2005). The best way to reward employees. Solutions for growing Business. www.entrepreneur.com Accessed 19 September 2013.

Saunders, M., Lewis, P. \& Thornhill, A. (2008). Research Methods for Business Students. (5 $5^{\text {th }}$ Ed). New York: Prentice Hall.

Sekaran, U. (2009). Research Methods for Business. A Skill Building approach. 4th Edition. New Delhi: John Wiley and Sons, Inc.

Senekal, E. (1998). ' $n$ Houdingstudie binne die raamwerk van die Herzberg Motiverings higi'ene teorie in 'n vervoerorganisasie. Unpublished Masters Dissertation at the RAU, Johannesburg.

Shaun \& York, A. (2002). Human Resource Management. London: Butterworth-Heinemann.

Stringer, C., Didham, J., \& Theivananthampillai, P. (2011). Motivation, pay satisfaction, and job satisfaction of front-line employees. Emerald 8, (2011).

Viswesvaran C., \& Ones D.S. (2000). Measurement error in Big Five factors personality

Welsh, E, Ganegoda, D \& Wiley, J. (2012). Is There Fire? Executive Compensation and Employee Attitudes. Personnel Review, 41 , 260-282. 
